\title{
Feltarbeid: religion i nærmiljøet
}

\author{
Av Lina Engelstad Snoek
}

$\ll$ «eg har loert at det finnes mange flere typer religion enn jeg har visst om. Det er større religioner, og mange små. Jeg synes det er rart å tenke på at folk tilhørende forskjellige religioner lever så ncert oss.» (Knut)

LiNA ENGELSTAD SNOEK, lektor ved Frogn videregående skole.

E-post: Lina.engelstad.snoek@frogn.vgs.no

På Frogn videregående skole har vi de siste årene startet opp undervisningen i religion og etikk på vg3 med et feltarbeid i nærmiljøet. ${ }^{1}$ Etter en introduksjon og diskusjon av religionsdefinisjoner og dimensjoner sender vi elevene ut for å utforske et religiøst eller religionsliknende fenomen, og presentere for klassen. Vi har to hovedtanker bak feltarbeidet: for det første å gjøre elevene bevisst på mangfoldet i religiøse uttrykk som til enhver tid utspiller seg rundt dem. For det andre å få dem til å bli kjent med tenkemåten i faget og bruke fagterminologien selvstendig så tidlig som mulig. Oppgaven er blitt en tradisjon som både elevene og vi lærerne setter stor pris på. I denne artikkelen presenterer jeg noen av mine egne erfaringer og respons som elevene gav i en refleksjonslogg på slutten av perioden, i september 2016. ${ }^{2}$ Elevsvarene er anonymisert.

\section{LITT OM ORGANISERING AV OPPLEGGET}

På Frogn er all undervisning lagt i fagdager, noe som innebærer at alle de tre uketimene i religion er lagt til samme dag. Vi setter som regel av fem uker til introduksjonsdelen til faget: to fagdager til introduksjon av fagbegreper og forberedelse til feltarbeid, en fagdag til selve feltarbeidet og to fagdager til fremføringer og refleksjonsnotat. Elevene bruker ikke nødvendigvis akkurat den tiden som er satt av til feltarbeid, til selve feltarbeidet. Rent praktisk er det ikke alltid mulig å besøke en religiøs organisasjon midt på dagen en hverdag, i hvert fall ikke hvis man skal overvære en rite. Her må vi derfor være litt romslige. Samtidig er det viktig at de skriver logg den dagen de har fătt satt av til feltarbeidet, forteller hvor langt de har kommet, og spør om ting de lurer på. og selvfølgelig må de få rask respons.

\footnotetext{
1 Se også tidligere artikkel om feltarbeid med elever i Snoek, Lina. 2012. »Metodikk på midtsidene: Religion i nærmiljøet» i Religion og livssyn 2/2012, årgang 24, gjentrykt i Religion og livssyn $\mathrm{nr}$ 2/2016.

2 Takk til elevene som lot meg bruke refleksjonsloggene sine i artikkelen!
} 
Våre elever går i grupper på to til tre. For å forhindre at noen faller for fristelsen til å seile på andres arbeid, setter vi som et vurderingskriterium at de fordeler fremføringen godt seg imellom. Elevene får beskjed om at de i utgangspunktet ville få en felles vurdering, men at vi åpner for individuelle karakterer dersom det skulle vise seg å være nødvendig. Det blir det stort sett ikke. Vi velger å sette måloppnåelse (høy/lav/middels) og ikke karakter på dette prosjektet, blant annet med tanke på at det er en øvingsoppgave tidlig i skoleåret der de skal bli kjent med faget og begrepene.

Når det gjelder hvilket religiøst fenomen de kan arbeide med, lar vi elevene få nokså vide rammer. Noen vil gjerne benytte anledningen til å opps $ø$ ke grupper som de ikke har kjennskap til, som Jehovas Vitner eller Scientologikirken, mens andre intervjuer en religiøs familie de kjenner. Tidligere år har noen elever også sett etter religiøse trekk ved yogasenteret eller snowboardklubben sin. Ved å la dem få velge selv får vi spilt på nysgjerrigheten deres, noe som er motiverende for elevene. Og når enkelte av fenomenene de opps $\emptyset$ ker, befinner seg i randsonen av hva som kan kalles en religion, får vi også diskutert religionsdefinisjonene slik de utspiller seg i møte med praksis.

\section{FREMFøRING AV FELTARBEIDET}

Vi setter altså av to fagdager (seks skoletimer) til fremføringer av feltarbeid, noe som kan høres mye ut. Imidlertid er det viktig for oss at de fremfører for hverandre og ikke bare for læreren, for at de skal bli bevisst på det religiøse mangfoldet rundt seg og lære av hverandre. Når vi setter av to fagdager, får vi tid til spørsmål og kommentarer etter hver fremføring, og her ligger det mye læring og refleksjon. Det går også an å gi elevene i oppgave å gi respons til hverandre for å sikre seg at de lytter aktivt. Etter fremføringene skriver hver elev en refleksjonslogg, med tanker om hva religion er og gjør, hva de har lært om det religiøse mangfoldet i nærmiljøet av å høre på andres presentasjoner, og hvordan de har opplevd det å utføre et feltarbeid.

På spørsmål om hva de har lært av andres fremføringer, var tilbakemeldingene i loggene i høst jevnt over positive og reflekterte. Samtidig var det nokså gjennomgående hvordan de opplevde at presentasjonene skapte et motbilde til hvordan enkelte religioner blir fremstilt i media, spesielt islam og Jehovas Vitner. Om presentasjonen fra et bes $\emptyset \mathrm{k}$ i en moské sa en elev for eksempel:

Spesielt det de fortalte om islam i forhold til media syntes jeg var spennende, fordi det er veldig aktuelt $i$ dag. De snakket mye om hvordan islam og muslimer ofte blir fremstilt negativt $i$ media, og at religionen har fått et dårlig rykte og ofte relateres med terror på grunn av handlingene til noen få ekstremister som bruker islam til å rettferdiggjøre handlingene sine. (Unni) 
En elev trakk frem presentasjonen om Jehovas Vitner som spesielt interessant og lærerik:

Jehovas vitner er et trossamfunn man hører en del om, ettersom de i enkeltsaker kan vare ganske kontroversielle. Likevel visste jeg selv ikke så veldig mye om trossamfunnet, bortsett fra den kritikken jeg har hørt om i media (her sikter jeg først og fremst til blodinfusjon). Jeg larte mer om selve trossamfunnet og hvordan det skiller seg fra kristendommen, noe som var interessant å høre på. (Nina)

Hvis man vurderer ut fra loggene, blir det altså tydelig at mange elever sitter med et bilde av religion som er nokså påvirket av medienes fremstillinger, men samtidig med et $\emptyset$ nske om å få dette bildet nyansert. Samtidig har jeg inntrykk av at fremføringene kan åpne opp for å gjøre elevene bevisst på hvor stort religi$\emptyset$ st mangfold det faktisk er rundt dem. En elev sier for eksempel:

Gjennom presentasjonene av feltarbeidene har jeg oppdaget at nœrmiljøet vårt er mye rikere på religioner enn jeg trodde. Mange av religionene/retningene det ble fortalt om visste jeg ikke engang at eksisterte i Norge. (Unni)

Min erfaring er altså at det er mye læring i fremføring av feltarbeidene, selv om det tar en del tid. For den som ikke har tid til fremføringer, kan et alternativ være innlevering av et produkt, for eksempel digital fortelling. Vi prøvde ut dette høsten 2015, men jeg var ikke like fornøyd med resultatet som ellers. Det ble vanskeligere å vurdere hvor godt gruppemedlemmene hadde fordelt oppgaven seg imellom, og når de ikke hørte hverandres beretninger, fikk de ikke det samme blikket for mangfoldet i lokalmiljøet. Det går likevel an å prøve en slags kombinasjon?

\section{FELTARBEID SOM EN MÅTE $̊$ ØVE INN BEGREPER PÅ}

I læreplanen står det blant annet at elevene skal kunne presentere religionsog livssyns-mangfoldet i lokalsamfunnet og storsamfunnet i Norge, diskutere ulike religionsdefinisjoner, presentere og drøfte ulike dimensjoner ved religionene og drøfte ulike former for religiøs søking i vår tid (Læreplan i religion og etikk, REL1-01). Definisjoner og dimensjoner kan bli litt abstrakt for elevene, men loggene gjenspeiler at begrepsapparatet blir litt mer virkelighetsnært for dem når de får innarbeide det i kombinasjon med å undersøke hva som rører seg i nærmiljøet.

Et av spørsmålene i refleksjonsloggen var: «Har du i løpet av feltarbeidet gjort deg noen tanker rundt forskjellen på innenfra- og utenfra-perspektiv på religion? Forklar.» Her uttrykte en elev at

Jeg føler absolutt at jeg forstår mer av forskjellen på innenfra- og utenfra-perspektiver på religion. Det er lett å tenke at man kan sette seg inn i et innenfra-perspektiv på 
et trossamfunn/religion/religiøst fenomen, uten å selv ha noen form for tilknytning til troen. Likevel merket jeg gjennom feltarbeidet at det ikke stemmer; de vi snakket med hos Frelsesarmeen hadde et veldig personlig og næert forhold til sitt trossamfunn, som vi (gruppa) ikke kunne prøvd å satt oss inn i. (Nina)

En annen flettet inn tanker om substansielle og funksjonelle religionsdefinisjoner i svaret sitt:

Utenfra kan religion ofte virke rart og annerledes for mange, kanskje litt overveldende. Dette fører ofte til at folk er kritiske til religion. Jeg vil tro at religion ofte her defineres med substansielle definisjoner. Men for de med innenfra-perspektiv er religion ofte en levemåte, og hva religionen gjør for dem er da ofte mer sentralt, altså funksjonelle definisjoner. (Iselin)

Begrepsbruken blir ikke nødvendigvis perfekt av et feltarbeid i starten av skoleåret, men jeg vil likevel si at mange elever opparbeider seg en tidlig bevissthet rundt fagbegreper. Dette er et godt utgangspunkt for å arbeide videre med religionene i løpet av skoleåret.

\section{Feltarbeid som holdningsarbeid}

Et formål med faget religion og etikk er å «bidra til kunnskap om og respekt for ulike religiøse, livssynsmessige og etiske ståsteder i lokalt, nasjonalt og globalt perspektiv» (Læreplan i religion og etikk, REL1-01, min utheving). Hvordan fungerte dette i feltarbeidet?

Som nevnt opplevde flere elever det som tankevekkende å lære om islam og Jehovas Vitner med et annet blikk enn det man typisk møter i media. En elev som bes $\emptyset$ kte Jehovas Vitner, var i utgangspunktet litt skeptisk til dem, men oppdaget at de kunne være hyggelige:

Jeg vet ikke om resten av gruppa mi, men jeg var ganske overrasket over hvor vennlig

Jehovas Vitner er. Fra det jeg leste på nett, hadde jeg bygget opp en mening at de er mennesker som du burde styre unna. Dette prosjektet viste meg en annen side av Jehovas vitner.(William)

Noe av det samme fortalte en som besøkte Scientologikirken:

Scientologikirken er nok en av de religiøse gruppene der innenfra og utenfra-perspektivet er størst. I media blir scientologer ofte fremstilt som «dårlig» folk, men hvis man hører på medlemmene vil de for det meste hjelpe folk.(Olav)

Mitt inntrykk er altså at feltarbeidet er en god måte å arbeide med respekt for andres religioner og livssyn på. Dette gjenspeiles også i svar på spørsmål i loggen om hvilke egenskaper elevene oppfattet som viktig å trene i faget religion og 
etikk. Åpenhet og refleksjon gikk igjen i svarene. Her er to eksempler:

Jeg synes at den viktigste egenskapen å trene på er religionsforståelse og en evne til å vcere åpen. Det kan hjelpe med å bli kvitt frykten og utestengelsen av religioner og folkeslag. Noe som er ekstremt viktig i dagens multikulturelle samfunn. Det er ille at folk skal holde seg unna helt vanlige mennesker bare på grunn av dems valg av tro. Jeg mener derfor at om en kan gjøre vårt samfunn mer forstående og åpent, kan vi bli kvitt frykten og misforståelsene for andre religioner. (Erik)

Det som er viktig i dette faget er å kunne vere åpen om for å lare å forstå de forskjellige religionene. Ikke bare for å få en forståelse for hvordan andre mennesker ser på verden på men også for å kunne skape en bedre verden senere når man læerer å leve med de andre religionene fordi man har fått opplering og forståelse $i$ en nokså tidlig alder. Jeg syntes at det er veldig spennende, spesielt med feltarbeid for da fär du opplevd hvordan det er og spurt de spørsmålene du lurer på til en som faktisk er med i den religionen du lerer om. Siden religion ikke er et nytt fag men man ikke har hatt det på noen år er det litt morsomt å huske noe av det man leerte å nå få et større syn på det fordi man klarer å reflektere enda mer. (Rikke)

Avslutningsvis vil jeg si at selv om feltarbeid kan være et tidkrevende prosjekt, er læringsutbyttet stort for forståelsen av faget. Begrepsapparatet, bruken av de ulike dimensjonene og forståelsen av religionsdefinisjonene synes jeg jevnt over blir bedre i kull der vi har hatt feltarbeid, enn når vi ikke har tatt oss tid til dette. Vi opplever at det å utforske religion i nærmiljøet blir en fin måte å få opp nysgjerrigheten for faget, og på mange måter også en døråpner for å forstå at religion er så mye forskjellig, avhengig av hvilke definisjoner og perspektiver man tar utgangspunkt i. 